\title{
Development time, body mass and length of immatures of Paralucilia fulvinota (Bigot, 1877) (Diptera: Calliphoridae) reared under natural conditions in a Central Amazon forest \\ Tempo de desenvolvimento, massa e comprimento corporal de imaturos de Paralucilia fulvinota (Bigot, 1877) (Diptera: Calliphoridae) criados sob condições naturais em uma floresta da Amazônia central
}

\author{
Tohnson Sales' (D) | Ruth Leila Ferreira-Keppler' (1) | Renato Tavares Martins' (1) | Luana Machado Barros' \\ Instituto Nacional de Pesquisas da Amazônia. Coordenação de Biodiversidade. Manaus, Amazonas, Brasil
}

\begin{abstract}
Blow flies (Calliphoridae) are used in forensic entomology studies, because their life cycle help to determine the minimum post-mortem interval (PMI ${ }_{\text {min }}$. Paralucilia fulvinota (Bigot, 1877) is a forensic indicator and is reported from human corpses in the Amazonian region. Our objectives were to describe the development time of $P$. fulvinota under natural conditions at Ducke Reserve (Amazonas), provide the accumulated degree-days (ADD) and accumulated degree-hour (ADH), body length and mass of larvae, and the sex ratio of adults. Pregnant females were sampled on a swine carcass. From hatched eggs, we reared stock colonies and observed the immature development under uncontrolled conditions of temperature $\left(24.5 \pm 1.3^{\circ} \mathrm{C}\right)$, rainfall $\left(188 \pm 11.5 \mathrm{~mm}^{3}\right)$ and humidity $(84 \pm 3.9 \%)$. Development time was 11 days. Adult sex ratio was 0.86 . Larvae gained mass at constant rates through the instars but grew less in length from the second to the third instar. Accordingly, $P$. fulvinota grows more in mass than in length when in larval stage. The period from first stadium to adults lasted 159.5 degree-days and 3828 degree-hours. Our results may be helpful in providing a more accurate estimate of $\mathrm{PMI}_{\min }$ on corpses encountered in forested areas of the Amazon region.
\end{abstract}

Keywords: Blow flies. Bionomy. Forensic entomology. Post-mortem interval.

Resumo: Moscas varejeiras (Calliphoridae) são usadas na entomologia forense, pois seu ciclo de vida ajuda a determinar o intervalo pós-morte mínimo (IPM ${ }_{\text {min }}$ ). Paralucilia fulvinota (Bigot, 1877) é considerada indicadora forense e é relatada em cadáveres humanos na região amazônica. Nossos objetivos foram descrever o tempo de desenvolvimento dessa espécie em condições naturais na Reserva Ducke (Amazonas), informar sobre grau-dia acumulado (GDA) e grau-hora acumulado $(\mathrm{GHA})$, comprimento e massa corporal das larvas e a razão sexual de adultos. Fêmeas grávidas foram criadas em carcaça suína. A partir de ovos eclodidos, criamos colônias de estoque e estudamos o desenvolvimento dos imaturos sob condições não controladas de temperatura $\left(24,5 \pm 1,3^{\circ} \mathrm{C}\right)$, precipitação $\left(188 \pm 11,5 \mathrm{~mm}^{3}\right)$ e umidade $(84 \pm 3,9 \%)$. tempo de desenvolvimento foi de 11 dias. A razão sexual foi de 0,86 . As larvas ganharam massa a taxas constantes através dos ínstares, mas cresceram menos do segundo para o terceiro ínstar. Consequentemente, $P$. fulvinota cresce mais em massa do que em comprimento durante o estágio larval. O período de primeiro estádio a adulto durou 159,5 graus-dia

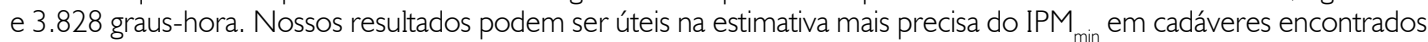
em áreas florestais da região amazônica.

Palavras-chave: Mosca varejeira. Bionomia. Entomologia forense. Intervalo pós-morte.

SALES, T., R. L. FERREIRA-KEPPLER, R. T. MARTINS \& L. M. BARROS, 2021. Development time, body mass and length of immatures of Paralucilia fulvinota (Bigot, 1877) (Diptera: Calliphoridae) reared under natural conditions in a Central Amazon forest. Boletim do Museu Paraense Emílio Goeldi. Ciências Naturais 16(1): 51-58. DOI: http://doi.org/10.46357/bcnaturais.v16i1.319.

Autora para correspondência: Luana Machado Barros. Instituto Nacional de Pesquisas da Amazônia. Coordenação de Biodiversidade. Campus II. Av. Bem-Te-VI, 8406, Bairro Petrópolis. Manaus, AM, Brasil. CEP 69067-001 (barrosluana222@gmail.com).

Recebido em 18/06/2020

Aprovado em 12/10/2020

Responsabilidade editorial: Valéria Juliete Silva
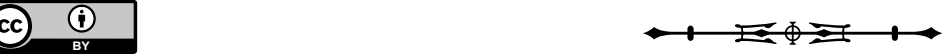


\section{INTRODUCTION}

Necrophagous insects are crucial in the decomposition process of cadavers (Feddern et al., 2019). Among the insects that visit corpses, Diptera and Coleoptera may represent up to $60 \%$ of the fauna found throughout the decomposition process (Charabidze et al., 2014; Mariani et al., 2014). Blow flies (Diptera: Calliphoridae) are among the first organisms to arrive in newly deceased corpses (Archer, 2003), because they are highly attracted by the odors released even at long distances (Anderson, 2009). Thus, Calliphoridae is a good forensic indicator and is often used for the determination of the minimum post-mortem interval $\left(\mathrm{PMI}_{\min }\right)$ (Vairo et al., 2015; Faris et al., 2016; Abd-Algalil et al., 2017).

The $\mathrm{PMI}_{\min }$ is usually based on the minimal age of insects associated with the corpses (Nuorteva, 1977), and can be estimated using fly larval body mass and length data (Greenberg \& Kunich, 2002). However, the main method to obtain the PMI is using accumulated degree-day (ADD), which is based on an estimated linear relationship between developmenttime and rearing temperature of insects (Amendt et al., 2007). This relationship can only be linear under controlled conditions of temperature (Higley \& Peterson, 1994); under uncontrolled conditions, the temperature varies in a hyperbolic manner (Ikemoto \& Takai, 2000).

Most studies on the life cycle of Calliphoridae have been conducted under controlled temperature (Lecheta et al., 2015; Bambaradeniya et al., 2019); however, small variations in temperature may result in alteration of the development time (Grassberger \& Reiter, 2002). For example, species of Calliphoridae from different geographic regions may present divergent responses to temperature because they are intrinsically adapted to different conditions (Grassberger \& Reiter, 2002).

The first study on the development time of the larval stages of Paralucilia fulvinota (Bigot, 1877) (Diptera: Calliphoridae) under uncontrolled temperature was performed by Greenberg \& Szyska (1984) in the Peruvian Amazonia. The first application of forensic entomology in the Brazilian Amazonia was performed by Pujol-Luz et al. (2006).
In this study, larvae of Paralucilia fulvinota were used to estimate the minimum post-mortem interval $\left(\mathrm{PMI}_{\min }\right)$ of the corpses. The difficulty highlighted by the application of forensic entomology in the Amazon is related to the lack of knowledge about the biology of necrophagous insects (Pujol-Luz et al., 2006). Considering the importance of $P$. fulvinota as a forensic indicator, we conducted a study of this species as a way to provide the first information on ADD and accumulated degree-hour $(\mathrm{ADH})$, body length and mass of immature stages, and the sex ratio of adults. Additionally, we provide a table with the development time in our study and those reported in previous papers. Our results may support $\mathrm{PMI}_{\text {min }}$ calculation in criminal cases that involves entomological evidence in a Central Amazon forest.

\section{MATERIAL AND METHODS}

This study was conducted at Ducke Reserve

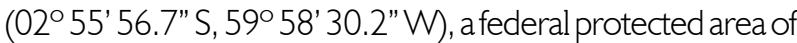
10,000 ha located on the $\mathrm{km}-26$ of the AM-10 road in Manaus, Amazonas, Brazil. The region has an equatorial climate, with a mean annual temperature of $\sim 26^{\circ} \mathrm{C}$ (variation: 23.3-31. $4^{\circ} \mathrm{C}$ ), a mean annual rainfall of $\sim 2,286 \mathrm{~mm}^{3}$ and a mean relative humidity of $\sim 80 \%$ (Costa et al., 2013).

This experiment was performed between October and December 2014. The eggs were obtained from mature females of Paralucilia fulvinota collected from a carcass of Sus scrofa (Linnaeus, 1758) (ethical committee protocol: $n^{\circ}$ 007/2014-CEUA/UFAM). The females were placed inside rearing cages under uncontrolled temperature and humidity with a photoperiod of 12L:12D and were offered beef to stimulate the oviposition. The laid eggs were transferred to Petri plates containing $1 \mathrm{~g}$ of beef, with moistened filtering paper on the bottom.

Six replicate units were used, each containing 60 larvae and $60 \mathrm{~g}$ of beef for feeding. The larvae food was not replaced throughout the experiment. We used the individuals (sample unit) of one replicate to assess larval body mass and length throughout the development. The immatures were kept under environmental 
temperature, which was recorded using a digital thermohygrometer (TH50, Incoterm).

To determine the development time, we made hourly observations from the oviposition period until the hatch of the eggs. Afterwards, observations were restricted to 12-hour intervals, and continued until the larvae ceased feeding (Queiroz, 1996). Then, we counted, weighted, and individualized each third-instar larvae in separate $15-\mathrm{mL}$ Falcon vials. Observation continued until all adults had emerged. Each day, from each larval instar, we separated six of the total number of reared larvae from one replicate unit. Posteriorly, the larvae were killed with hot distilled water and preserved in 96\% ethylic alcohol (Bugelli et al., 2017). We identified the instars based on their spiracle openings (Queiroz et al., 1997). The sex ratio of adults was calculated following Silveira-Neto et al. (1976). The mature females were identified using the key proposed by Amat (2009).

To evaluate the growth of Paralucilia fulvinota, we measured body mass and length. These measurements were taken under a Leica M165C stereomicroscope with calibrated lens (accuracy $=0.001 \mathrm{~mm}$ ). Larval body length was measured as the distance from the cephalic segment to the distal margin of the final abdominal segment, considering any flexion of the larval body. The weighing of wet mass was performed for all three instars using a scale (ML, Mettler-Toledo, Columbus, EUA, accuracy = $0.01 \mathrm{mg}$ ). Larval growth was estimated according to the difference of weight and size between subsequent instars. We performed analysis of variance (ANOVA) in order to verify whether body mass differed among instars. This analysis is too used to test difference of length among instars. Statistically significant test was $p<0.05$. All analysis was made in statistical software $R$ (R Core Team, 2016).

To calculate accumulated degree-hour (ADH) and accumulated degree-day $(\mathrm{ADH})$, we established a minimum temperature of $10^{\circ} \mathrm{C}$. We did so because there is no existing data on the thermal demands of $P$. fulvinota, and $10^{\circ} \mathrm{C}$ is the bottom limit suggested for Neotropical species (Higley \& Peterson, 1994). The temperature records were obtained from the Ducke Reserve Meteorological Station. We used $24.5^{\circ} \mathrm{C}$ as the mean temperature, with 27.6 ${ }^{\circ} \mathrm{C}$ and $21.1^{\circ} \mathrm{C}$ as the maximum and minimum values, respectively. We followed Higley \& Haskell (2003) to calculate ADD and ADH from the formulas below.

$$
\begin{gathered}
\mathrm{ADD}=(\text { rearing temperature }- \text { minimum threshold }) \times \\
\text { development time }
\end{gathered}
$$

$\mathrm{ADH}=($ rearing temperature- minimum threshold $) \times$ development time

$$
24
$$

\section{RESULTS}

We observed a larval survival rate of $14.72 \%$, meaning that only 53 out of the 360 initial larvae developed into adults. Overall development time (immature + imago) lasted around 11 days (264 h). On average, the first-larval instar (L1) lasted 12 hours, the second-larval instar (L2) lasted 36 $\mathrm{h}$, and the final instar (L3) lasted $72 \mathrm{~h}$. Overall, larval stages L1-L3 lasted on average $120 \mathrm{~h}$, while the pupal stage lasted around $144 \mathrm{~h}$ (Table 1). The sexual ratio was 0.86 , with 46 females and seven males.

During development, the body length at egg hatching stayed around $2.72 \pm 0.17 \mathrm{~mm}$. Sixty hours after hatching, the third instar larvae were an average of $11.45 \pm 1 \mathrm{~mm}$ long, thus significantly larger than L1 (3.05 $\pm 0.4 \mathrm{~mm})$ and L2 (6.35 \pm 1.38 ) (ANOVA: $F_{2,33}=119.66 ; p<0.001$ ). Larvae grew more in length from the first to the second instar $(4.48 \mathrm{~mm})$ than from the second to the third instar (3.58 mm; Figure 1).

The larval mass increased approximately $420 \%$. Larval mass at egg hatching was $0.09 \mathrm{mg}$, and after $60 \mathrm{~h}$ (L3), recorded weight was $31.67 \pm 5.09 \mathrm{mg}$ (Figure 2). Third instar larvae were significantly heavier than first (0.32 $\pm 0.38 \mathrm{~mm}$ ) and second instar ones $(6.59 \pm 4.6)$ (ANOVA: $\left.F_{2,33}=134.36 ; p<0.001\right)$. Contrary to the trend observed in body length, larvae gained more mass from the second to the third instar (19.22 mg) than from the first to the second instar (11.89 mg). 
The estimates of ADD and ADH for development time of Paralucilia fulvinota were 159.5 and 3828, respectively. In both indexes, the values for $\mathrm{L} 1$ were lower than other stages (Table 2).

\section{DISCUSSION}

We obtained a low emergence rate (14.72\%). Pérez et al. (2016) also observed a low percentage of emergence in the first generation of Calliphora vicina Robineau-

Table 1. Comparison of our results with other studies regarding the development time of Paralucilia Brauer \& Bergenstamm, 1891 species under natural conditions of temperature (temp; $\left.{ }^{\circ} \mathrm{C}\right)$. We demonstrate that development time differs even among closely related species. Legends: ${ }^{1}=$ Greenberg \& Szyska (1984); ${ }^{2}=$ Pujol-Luz et al. (2006); ${ }^{3}=$ Barros-Souza et al. (2012); ${ }^{4}$ = Sales et al. (2013); ${ }^{5}=$ our study.

\begin{tabular}{c|c|c|c|c|c|c}
\hline \multirow{2}{*}{ Species } & \multirow{2}{*}{ Temp } & \multicolumn{5}{|c}{ Average development time (hours) } \\
\cline { 3 - 7 } & & L1 & L2 & L3 & Pupa & Total \\
\hline Paralucilia fulvinota $^{*}$ & \multirow{2}{*}{$21.7-26.0$} & 18 & 20.5 & 99 & 120 & 257.5 \\
\cline { 3 - 8 } & & 26 & 12 & 183 & 120 & 341 \\
\hline Paralucilia fulvinota $^{2}$ & 26.0 & 30.3 & 16 & 118 & 122.3 & 286.6 \\
\hline Paralucilia paraensis $^{3}$ & 25.8 & 11.4 & 13 & 81.1 & 144.14 & 249.64 \\
\hline Paralucilia paraensis $^{4}$ & 26.0 & 13 & 18 & 46 & 96 & 173 \\
\hline Paralucilia fulvinota $^{5}$ & 24.5 & 12 & 36 & 72 & 144 & 264 \\
\hline
\end{tabular}

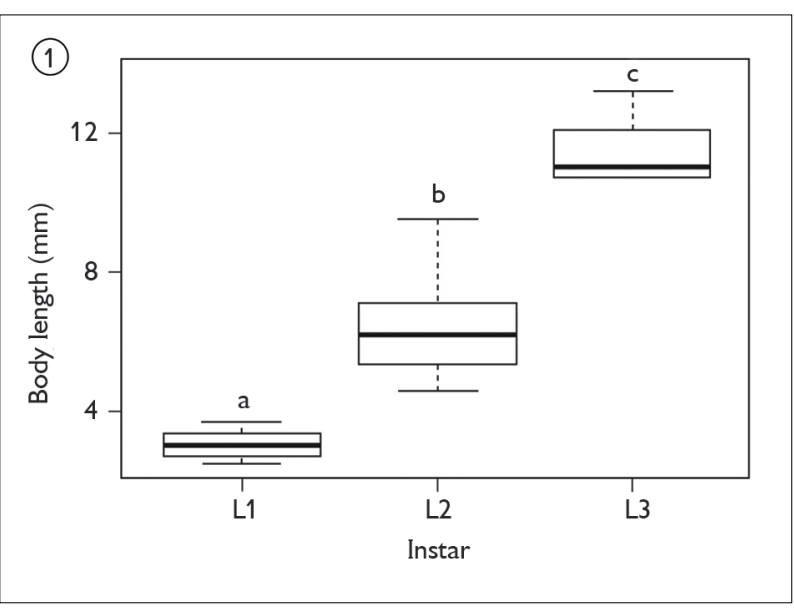

Figure 1. Body length ( $\mathrm{mm}$ ) of larvae of Paralucilia fulvinota (Bigot, 1877) reared under uncontrolled conditions of temperature with average value of $24.5^{\circ} \mathrm{C}$ in Ducke Reserve, Manaus, AM. Legends: $\mathrm{a}(\mathrm{L} 1)=$ larvae of $1^{\text {st }}$ instar; $\mathrm{b}(\mathrm{L} 2)=$ larvae of $2^{\text {nd }}$ instar; and c (L3) $=$ larvae of $3^{\text {rd }}$ instar.

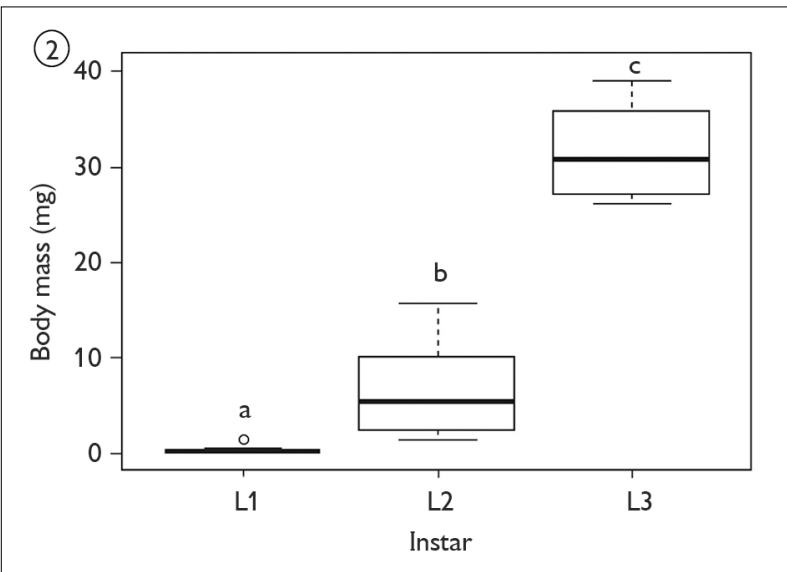

Figure 2. Body mass (mg) of larvae of Paralucilia fulvinota (Bigot, 1877) reared under uncontrolled conditions of temperature with average value of $24.5^{\circ} \mathrm{C}$ in Ducke Reserve, Manaus, AM. Legends: $\mathrm{a}(\mathrm{L} 1)=$ larvae of $1^{\text {st }}$ instar; $\mathrm{b}(\mathrm{L} 2)=$ larvae of $2^{\text {nd }}$ instar; and c (L3) $=$ larvae of $3^{\text {rd }}$ instar.

Table 2. Accumulated degree-hour (ADH) and Accumulated degree-day (ADD) for the larval and pupal development of Paralucilia fulvinota (Bigot, 1877) in Ducke Reserve, Manaus, AM, Brazil. The values were calculated using $24.5^{\circ} \mathrm{C}$ as temperature and $10^{\circ} \mathrm{C}$ as bottom limit (Higley \& Peterson, 1994).

\begin{tabular}{c|c|c|c|c|c}
\hline \multirow{2}{*}{ Index } & \multicolumn{5}{|c}{ Stages } \\
\cline { 2 - 6 } & L1 & L2 & L3 & Pupa & Total \\
\hline ADH & 174.00 & 522.00 & 1044.00 & 2088.00 & 3828.00 \\
\hline ADD & 7.25 & 21.75 & 43.5 & 87 & 159.5 \\
\hline
\end{tabular}

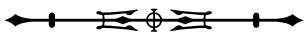


Desvoidy, 1830. One of the factors that may have influenced our results is diet. We opted to use beef to feed the larvae. This resource is used in the rearing of flies for forensic study (Souza \& Kirst, 2010). Nevertheless, the low emergence rate of adults may indicate that the amount of food offered may not have been sufficient for the larvae to complete their energy reserve. During development, the larvae compete for the food resource (personal observation) and some may not assimilate the nutrients necessary to achieve pupation (Gobbi et al., 2013). Furthermore, survive rate is higher for wild immatures than for those reared in the laboratory, which is likely due to wild larvae having access to additional nutrients (Dicke et al., 1989). It is also possible that the laboratory larvae experience stress caused by the inability to migrate to bury themselves in a space that is relatively small compared to the natural environment. This situation was also observed during a study of the development of Lucilia eximia (Wiedemann, 1819) (Calliphoridae) in Colombia (Vélez \& Wolff, 2008). Paralucilia fulvinota was recorded in Peru and Brazil (see Table 2) under a temperature range of $21.7^{\circ} \mathrm{C}$ to $26^{\circ} \mathrm{C}$. In Peru, the development from L1 to pupa was approximate ( $\sim 12.5$ days; 299.3 h) to our study (Greenberg \& Szyska, 1984). In Brazil, Pujol-Luz et al. (2006) used a development time of $\sim 287$ h, 23 h longer than our study. This difference of $\sim 1$ day is relevant, mainly because both studies were performed in Amazonas state. This difference can be related to the diet used during the rearing of the larvae. Pujol-Luz et al. (2006) used pork in the rearing of $P$. fulvinota, while the present study used beef. For example, larvae of Chrysomya putoria (Wiedemann, 1830) (Calliphoridae) needed more time to develop when reared with swine liver compared to bovine liver (Salazar-Souza et al., 2019).

In urban (Barros-Souza et al., 2012) and forested (Sales et al., 2013) areas of Manaus (Amazonas, Brazil), the development time of $P$. paraensis (Mello, 1969) differ from what we observed with $P$. fulvinota regarding overall development time and duration of instars. This demonstrates that even morphologically similar species may display differences in life cycle.

We recorded a higher number of females compared to males. On the other hand, Barros-Souza et al. (2012) registered a 1:1 ratio in P. paraensis. Although we may expect a similar quantity of males and females (e.g. Boatright \& Tomberlin, 2010; Liet al., 2014), some females of Calliphoridae species (e.g. Chrysomya albiceps (Wiedemann, 1819)) can reproduce in a monogenetic manner (Serra et al., 2007).

Through the values of body mass and length, we could observe that the juveniles gained more mass than length. Thus, length measurements may not be appropriate variables with which to determine instar and development time in blow flies. Furthermore, according to Day \& Wallman (2006), the larvae develop a slight bend on the anterior edge of the ventral side, which may mislead measurements. To overcome this issue, it was suggested that studies should use the junction of the width of the fifth and sixth segments in relation to body length (Day \& Walmann, 2006).

In an urban area of Manaus, Barros-Souza et al. (2012) registered 4841.06 degree-hours and 201.71 degree-days for $P$. paraensis in uncontrolled conditions of temperature. Such values were similar to those recorded by our study $(\mathrm{ADH}=3828 ; \mathrm{ADD}=159.5)$ and the differences may be due to the variation between the study areas (urban versus primary forest), species-specific features, and the climatic conditions of the experiments. Furthermore, studies conducted under uncontrolled temperature conditions are fundamental for obtaining more accurate values of PMI (Barros-Souza et al., 2012), as forensic entomology practices are applied in dynamic environments.

Studies with blow flies of forensic value are rather common in several regions (Nabity et al., 2006; Badenhorst \& Villet, 2018; Langer et al., 2019). However, bionomic data on necrophagous species should not be extrapolated to differences localities, as this may mislead the PMI estimations (Barros et al., 2019). Therefore, the precise development of data for forensic indicator species is essential for accuracy in PMI estimates (Nabity et al., 2006). 


\section{CONCLUSION}

This study presents bionomic data on P. fulvinota in Amazonas state under uncontrolled conditions, contributing information on development time. It is the first study with data on $A D H, A D D$, and growth rates for larval stages of this species. This information is important in order to minimize errors in the calculation of $\mathrm{PMI}_{\text {min }}$ for subsequent utilization in medico-legal procedures. Moreover, our data may provide useful bionomic information on $P$. fulvinota for solving crimes associated with forested areas of similar characteristics in which this species is an entomological vestige.

\section{ACKNOWLEDGMENTS}

We are grateful to Dr. Rubens Pinto de Mello for identification confirmation of Paralucilia fulvinota and Dr. Margareth Queiroz for suggestions in experimental design. TS received a master's scholarship from the Conselho Nacional de Desenvolvimento Científico e Tecnológico (CNPq). RLFK received research fellowships (Process: 307039/2016-1) from the CNPq. LMB received a Fellowship Ph.D. from the CNPq. RTM received a fellowship from the Programa de Apoio à Fixação de Doutores no Amazonas (FIXAM/AM) (FAPEAM). The present work was supported in part by PRONEX/ CNPq/FAPEAM-Aquatic insects and INCT ADAPTA II funded by CNPq - Brazilian National Research Council (465540/2014-7), FAPEAM - Amazonas State Research Foundation (062.1187/2017), and CAPES - Coordination for the Improvement of Higher Education Personnel.

\section{REFERENCES}

ABD-ALGALIL, F. M. A., S. P. ZAMBARE, L. A. KHAN \& K. H. MALI, 2017. Effect of seasonal temperature variations on the life cycle duration of forensically important calliphorid fly, Chrysomya saffranea (Bigot, 1877). Journal of Forensic Research 8: 1-6. DOI: https://doi.org/10.4172/2157-7145.1000364

AMAT, E., 2009. Contribuición al conocimiento de las Chrysominae y Toxotarsinae (Diptera: Calliphoridae) de Colômbia. Revista Mexicana de Biodiversidad 80: 693-708.
AMENDT, J., C. P. CAMPOBASSO, E. GAUDRY, C. REITER, H. N. LEBLANC \& M. J. HALL, 2007. Best practice in forensic entomology - standards and guidelines. International Journal of Legal Medicine 121(2): 90-104. DOI: https://doi.org/10.1007/ s00414-006-0086-x

ANDERSON, G. S., 2009. Factors that influence insect succession on carrion. In: J. L. BYRD \& J. H. CASTNER (Ed.): Forensic entomology: the utility of arthropods in legal investigations: 201250. CRC Press, Boca Raton.

ARCHER, M. S., 2003. Annual variation in arrival and departure times of carrion insects at carcasses: implications for succession studies in forensic entomology. Australian Journal Zoology 51(6): 569-576. DOI: https://doi.org/10.1071/ZO03053

BADENHORST, R. \& M. H. VILLET, 2018. The uses of Chrysomya megacephala (Fabricius, 1794) (Diptera: Calliphoridae) in forensic entomology. Forensic sciences research 3(1): 1-14. DOI: https:// doi.org/10.1080/20961790.2018.1426136

BAMBARADENIYA, Y. T. B., W. A. I. P. KARUNARATNE, J. K. TOMBERLIN, I. GOONERATHNE, R. B. KOTAKADENIYA \& P. MAGNI, 2019. Effect of temperature and tissue type on the development of the forensic fly Chrysomya megacephala (Diptera: Calliphoridae). Journal of Medical Entomology 56(6): 1571-1581. DOI: https://doi.org/10.1093/jme/tjz097

BARROS, L. M., R. L. FERREIRA-KEPPLER, R. T. MARTINS \& A. L. N. GUTJAHR, 2019. Bionomy of Hermetia illucens (Diptera: Stratiomyidae) on decomposing swine carcass in an urban area of Central Amazon. Journal of Medical Entomology 56(3): 681-689. DOI: https://doi.org/10.1093/jme/tjz005

BARROS-SOUZA, A. S., R. L. FERREIRA-KEPPLER \& D. B. AGRA, 2012. Development period of forensic importance Calliphoridae (Diptera: Brachycera) in urban area under natural conditions in Manaus, Amazonas, Brasil. EntomoBrasilis 5(2): 99-105. DOI: https://doi.org/10.12741/ebrasilis.v5i2.201

BOATRIGHT, A. S. \& J. K. TOMBERLIN, 2010. Effects of temperature and tissue type on the development of Cochliomyia macellaria (Diptera: Calliphoridae). Journal of Medical Entomology 47(5): 917-923. DOI: https://doi.org/10.1093/ jmedent/47.5.917

BUGELLI, V., C. P. CAMPOBASSO, M. A. VERHOFF \&J. AMENDT, 2017. Effects of different storage and measuring methods on larval length values for the blow flies (Diptera: Calliphoridae) Lucilia sericata and Calliphora vicina. Science \& Justice 57(3): 159-164. DOI: https://doi.org/10.1016/j.scijus.2016.10.008

CHARABIDZE, D., T. COLARD, B. VINCENT, T. PASQUERAULT \& V. HEDOUIN, 2014. Involvement of larder beetles (Coleoptera: Dermestidae) on human cadavers: a review of 81 forensic cases. International Journal of Legal Medicine 128: 1021-1230. DOI: https://doi.org/10.1007/s00414-013-0945-1

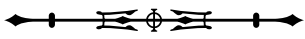


COSTA, A. C. L., J. A. S. JUNIOR, A. C. CUNHA, J. R. P. FEITOSA, B. T. T. PORTELA, G. G. C. SILVA \& R. F. COSTA, 2013. Índices de conforto térmico e suas variações sazonais em cidades de diferentes dimensões na Região Amazônica. Revista Brasileira de Geografia Física 6(3): 478-487.

DAY, D. M. \& J. F. WALLMAN, 2006. Influence of substrate tissue type on larval growth in Calliphora augur and Lucilia cuprina (Diptera: Calliphoridae). Journal of Forensic Science 51(3): 657-663. DOI: https://doi.org/10.1111//.1556-4029.2006.00127.x

DICKE, M., M. DEJONG, M. P. T. ALERS, F. C. T. STELDER, R. WUNDERINK \& J. POST, 1989. Quality control of mass-reared arthropods: nutritional effects on performance of predatory mites. Journal of Applied Entomology 107: 462-475.

FARIS, A. M., H. H. WANG, A. M. TARONE \& W. E. GRANT, 2016. Forensic entomology: evaluating uncertainty associated with postmortem interval (PMI) estimates with ecological models. Journal of Medical Entomology 53(5): 1117-1130. DOI: https://doi. org/10.1093/jme/tjw070

FEDDERN, N., E. A. MITCHELL, J. AMENDT, I. SZELECZ \& C. V. SEPPEY, 2019. Decomposition and insect colonization patterns of pig cadavers lying on forest soil and suspended above ground. Forensic Science, Medicine and Pathology 15: 342-351. DOI: https://doi. org/10.1007/s12024-019-00121-6

GOBBI, P., A. MARTÍNEZ-SÁNCHEZ \& S. ROJO, 2013. The effects of larval diet on adult life-history traits of the black soldier fly, Hermetia illucens (Diptera: Stratiomyidae). European Journal of Entomology 110(3): 461-468. Available at: http://www.eje.cz/pdfs/110/3/461. Accessed on: 10/01/2020

GRASSBERGER, M. \& C. REITER, 2002. Effect of temperature on development of the forensically important holartic blow fly Protophormia terranovae (Robineau-Desvoidy) (Diptera: Calliphoridae). Forensic Science International 128(3): 177-182. DOI: https://doi.org/10.1016/S0379-0738(02)00199-8

GREENBERG, B. \& L. M. SZYSKA, 1984. Immature stages and biology of fifteen species of Peruvian Calliphoridae. Annals of the Entomological Society of America 77(5): 488-515. DOI: https:// doi.org/10.1093/aesa/77.5.488

GREENBERG, G. \& J. C. KUNICH, 2002. Entomology and the law, flies as forensic indicators: 1-330. University Press, Cambridge.

HIGLEY, L. G. \& R. K. D. PETERSON, 1994. Initiating sampling programs. In: L. P. PEDIGO \& G. D. BUNTIN (Ed.): Handbook of sampling methods for arthropods in investigations: 120-136. CRC Press LLC, Boca Ranton.

HIGLEY, L. G. \& N. H. HASKELL, 2003. Insect development and forensic entomology. In: J. H. BYRD \& J. L. CASTNER (Ed.): Forensic entomology: the utility of arthropods in legal investigations: 287-302. CRC Press LLC, Boca Raton, Florida.
IKEMOTO, T. \& K. TAKAI, 2000. A new linearized formula for the law of total effective temperature and the evaluation of line-fitting methods with both variables subject to error. Environmental Entomology 29(4): 671-682. DOI: https://doi.org/10.1603/0046225X-29.4.671

LANGER, S. V., C. J. KYLE, M. ILLES, S. LARKIN \& D. V. BERESFORD, 2019. Urban and rural spatial delineations in blow fly species (Diptera: Calliphoridae) across Canada: implications for forensic entomology. Journal of Medical Entomology 56(4): 927935. DOI: https://doi.org/10.1093/jme/tjz047

LECHETA, M. C., P. J. THYSSEN \& M. O. MOURA, 2015. The effect of temperature on development of Sarconesia chlorogaster, a blowfly of forensic importance. Forensic Science, Medicine, and Pathology 11: 538-543. DOI: https://doi.org/10.1007/s12024015-9727-z

LI, X., Y. YANG, G. LI, H. LI, Q. WANG \& L. WAN, 2014. The effect of dietary fat levels on the size and development of Chrysomya megacephala (Diptera: Calliphoridae). Journal of Insect Science 14(1): 174. DOI: https://doi.org/10.1093/jisesa/ieu036

MARIANI, R., R. GARCIA-MANCUSO, G. L. VARELA \& A. M. INDA, 2014. Entomofauna of a buried body: study of the exhumation of a human cadaver in Buenos Aires, Argentina. Forensic Science International 237: 19-26. DOI: https://doi.org/10.1016/j. forsciint.2013.12.029

NABITY, P. D., G. L. HIGLEY \& T. M. HENG-MOSS, 2006. Effects of temperature on development of Phormia regina (Diptera: Calliphoridae) and use of developmental data in determining time intervals in forensic entomology. Journal of Medical Entomology 43(6): 1276-1286. DOI: https://doi.org/10.1093/jmedent/43.6.1276

NUORTEVA, P., 1977. Sarcosaprophagous insects as forensic indicators. In: C. G. TEDESCHI, W. G. ECKERT \& L. G. TEDESCHI (Ed.): Forensic medicine: a study in trauma and environmental hazards: v. 2: 1072-1095. W. B. Saunders Co., Pennsylvania.

PÉREZ, C., N. A. SEGURA, M. N. PATARROYO \& F. BELLO, 2016. Evaluating the Biological Cycle and Reproductive and Population Parameters of Calliphora vicina (Diptera: Calliphoridae) Reared on Three Different Diets. Journal of Medical Entomology 53(6): 1268-1275. DOI: https://doi.org/10.1093/jme/tjw114

PUJOL-LUZ, J. R., H. MARQUES, A. URURAHY-RODRIGUES, J. A. RAFAEL, F. H. SANTANA, L. C. ARANTES \& R. CONSTANTINO, 2006. A forensic entomology case from the Amazon rain forest of Brazil. Journal of Forensic Science 51(5): 1151-1153. DOI: https:// doi.org/10.1111/j.1556-4029.2006.00217.x

QUEIROZ, M. M. C., 1996. Temperature requirements of Chrysomya albiceps (Wiedemann, 1819) (Diptera, Calliphoridae) under laboratory conditions. Memórias do Instituto Oswaldo Cruz 91(6): 785-788. DOI: https://doi.org/10.1590/S007402761996000600027 
QUeIROZ, M. M. C., R. P. MELLO \& M. M. LIMA, 1997. Morphological aspects of the larval instars of Chrysomya albiceps (Diptera, Calliphoridae) reared in the laboratory. Memórias do Instituto Oswaldo Cruz 92(2): 187-196. DOI: https://doi. org/10.1590/S0074-02761997000200010

R CORE TEAM, 2016. R: a language and environment for statistical computing. R Foundation for Statistical Computing, Vienna, Austria.

SALAZAR-SOUZA, M., M. S. COURI \& V. M. AGUIAR, 2019. Post-embryonic development of Chrysomya putoria (Diptera: Calliphoridae) in swine and bovine tissues in South America: implications for forensic entomology. Austral Entomology 58(2): 329-335. DOI: https://doi.org/10.1111/aen.12311

SALES, T., R. L. FERREIRA-KEPPLER, A. OLIVEIRA-DA-SILVA \& A. S. B. SOUZA, 2013. Description of immature stages and development time of Paralucilia paraensis (Mello) (Diptera: Calliphoridae) associated with the decomposition of a partially submerged swine carcass. Neotropical Entomology 42: 211-215. DOI: https://doi.org/10.1007/ s13744-012-0097-x

SERRA, H., W. A. C. GODOY, F. J. VON ZUBEN, C. J. VON ZUBEN \& S. F. REIS, 2007. Sex ratio and dynamic behavior in populations of the exotic blowfly Chrysomya albiceps (Diptera, Calliphoridae). Brazilian Journal of Biology 67(2): 347-353. DOI: http://dx.doi.org/10.1590/S1519-69842007000200022
SILVEIRA-NETO, S., O. NAKANO, D. BARBIN \& N. M. VILLANOVA, 1976. Manual de ecologia de insetos: 1-419. Editora Agronômica Ceres, São Paulo.

SOUZA, A. S. B. \& F. D. KIRST, 2010. Aspectos da bionomia e metodologia de criação de Dipteros de interesse forense. In: $L$. GOMES (Ed.): Entomologia forense: novas tendências e tecnologias nas ciências criminais: 1. ed.: 169-182. Technical Books Editora, Rio de Janeiro.

VAIRO, K. P., R. C. CORRÊA, M. C. LECHETA, M. F. CANEPARO, K. M. MISE, D. PRETI, C. J. CARVALHO, L. M. ALMEIDA \& M. O. MOURA, 2015. Forensic use of a subtropical blowfly: the first case indicating minimum postmortem interval (mPMI) in southern Brazil and first record of Sarconesia chlorogaster from a human corpse. Journal of Forensic Science 60(s1): S257-S260. DOI: https://doi. org/10.1111/1556-4029.12596

VÉLEZ, C. \& M. WOLFF, 2008. Rearing five species of Diptera (Calliphoridae) of forensic importance in Colombia in semicontrolled field conditions. Papéis Avulsos de Zoologia 48(6): 41-47. DOI: https://doi.org/10.1590/S0031-10492008000600001

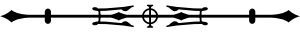

